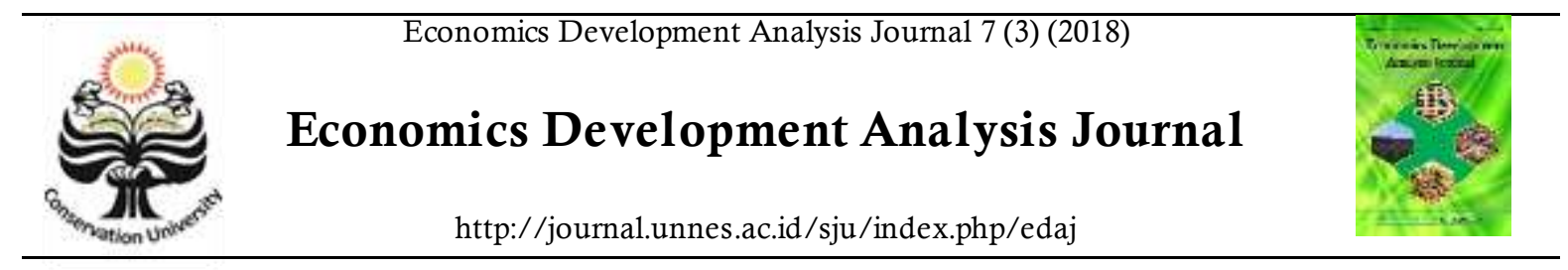

\title{
Strategi Pengembangan Industri Kerajinan Eceng Gondok di Kabupaten Semarang
}

\author{
Fatmawati $^{1 \bowtie}$, Deky Aji Suseno $^{2}$
}

Jurusan Ekonomi Pembangunan, Fakultas Ekonomi, Universitas Negeri Semarang

\begin{tabular}{l}
\hline Info Artikel \\
\hline Sejarah Artikel: \\
Diterima April 2018 \\
Disetujui Juni 2018 \\
Dipublikasikan Agustus \\
2018
\end{tabular}

Keywords:

AHP, Water Hyacinth

Crafts; Strategy

Development.

\begin{abstract}
Abstrak
Industri kerajinan eceng gondok di Kabupaten Semarang sangat potensial untuk dikembangkan, namun perkembangannya mengalami penurunan yang semula di tahun 2013 terdapat 18 unit usaha menurun menjadi 10 unit usaha di tahun 2015. Volume produksi di tahun 2015 juga mengalami penurunan jika dibandingkan dengan tahun 2014. Hal tersebut berbanding terbalik dengan ketersediaan bahan baku eceng gondok di Rawapening yang terus mengalami peningkatan. Sampel dalam penelitian ini terdiri dari 10 perajin dan 8 keyperson. Adapun metode penelitian yang digunakan adalah analisis deskriptif untuk mengetahui permasalahan industri dan Analisis Hierarki Proses (AHP) untuk menentukan strategi pengembangan industri kerajinan eceng gondok di Kabupaten Semarang. Hasil penelitian menunjukkan bahwa permasalahan mendasar yang dihadapi adalah masih terbatasnya SDM yang terampil. Prioritas utama dalam pengembangan industri kerajinan eceng gondok di Kabupaten Semarang adalah kriteria SDM (nilai bobot 0,463), disusul kriteria pemasaran (nilai bobot 0,347 ), kriteria manajemen produksi (nilai bobot 0,119 ), dan kriteria teknologi (nilai bobot 0,017 ). Adapun saran dari penelitian ini antara lain diharapkan pemerintah dan pihak yang berkepentingan lebih memfokuskan pengembangan industri kerajinan eceng gondok melalui peningkatan pengetahuan dan keterampilan teknis SDM melalui pendidikan dan pelatihan..
\end{abstract}

\begin{abstract}
Water hyacinth crafts industries in Semarang Regency potential for development, but its development has decreased which was originally in the year 2013, there are 18 business units decreased to 10 business units in 2015. The production volume in 2015 also decreased compared to 2014. The inversely proportional to the availability of raw materials in the water hyacinth Rawapening which is constantly increasing. Thesamplein this study consisted of 10 craftsmen and 8 keyperson. The research method used is descriptive analysis to find out the problems of industries and Analysis Hierarchy Process (AHP) to determine the development strategy of water hyacinth crafts industries in Semarang Regency. The results showed that the fundamental problemsfaced is the limited skilled human resources. The main priority in the development of water hyacinth craftsindustries in Semarang district is HR criteria (weight value 0.463), followed by marketing criteria (weight value 0.347), production management criteria (weight value 0.119 ), and technology criteria (weight value 0.017). The suggestion from this study are expected in the government and interested parties more focused developmentof water hyacinth crafts industries by enhancing the knowledge and technical skills of human resourcesthrough education and training
\end{abstract}




\section{PENDAHULUAN}

Sejak masa pemerintahan orde baru hingga saat ini, industrialisasi telah mengubah struktur perekonomian Indonesia. Dalam jangka waktu 30 tahun sejak 1967-1997 peran sektor industri terus meningkat, bahkan pada beberapa tahun terakhir pada masa tersebut peran sektor industri terhadap PDB sebesar 26,85 persen dan mampu melebihi peran sektor pertanian yang hanya sebesar 16,1 persen (Prasetyo, 2010). Peran sektor industri juga terus mengalami peningkatan di berbagai provinsi di Indonesia, tak terkecuali Provinsi Jawa Tengah. Pada tahun 2013-2015 sektor industri pengolahan selalu menempati urutan teratas dalam struktur ekonomi di Provinsi Jawa Tengah (BPS Provinsi Jawa Tengah 2016). Keadaan yang sama juga terjadi di salah satu kabupaten di Provinsi Jawa Tengah, yaitu di Kabupaten Semarang. Sektor industri pengolahan merupakan penyumbang PDRB terbesar. Hal ini sejalan dengan slogan INTANPARI yang menempatkan sektor industri pengolahan sebagai sektor andalan di Kabupaten Semarang. Besarnya kontribusi sektor industri pengolahan pada PDRB Kabupaten Semarang tersebut berkaitan dengan banyaknya industri kecil maupun menengah besar yang berlokasi di Kabupaten Semarang (BPS Kabupaten Semarang 2015).

Keberadaan industri kecil maupun menengah besar ini dapat mengurangi tingkat pengangguran, apalagi bagi industri kecil menengah yang masih bersifat padat karya dan memanfaatkan sumber daya manusia yang ada di sekitarnya. Menurut Thee (1993) dalam Kuncoro (2007), teknologi yang digunakan dalam industri kecil adalah teknologi padat karya sehingga bisa memperbesar lapangan kerja dan kesempatan usaha yang pada gilirannya mendorong pembangunan daerah dan kawasan pedesaan.

Menurut Kementerian Negara Koperasi dan Usaha Kecil dan Menengah dalam Rusdarti (2010:145) peranan Usaha Kecil dan Menengah (UKM) sangat besar dalam perekonomian nasional antara lain sebagai berikut: (1) mendorong munculnya kewirausahaan domestik dan sekaligus menghemat sumber daya Negara, (2) menggunakan teknologi padat karya, sehingga dapat menciptakan lebih banyak kesempatan kerja dibandingkan yang disediakan oleh perusahaan skala besar, (3) dapat didirikan, dioperasikan dan memberikan hasil dengan cepat, (4) pengembangannya dapat mendorong proses desentralisasi inter-regional dan intraregional, karena usaha kecil dapat berlokasi di kota-kota kecil dan pedesaan, (5) memungkinkan tercapainya obyektif ekonomi dan sosial-politik dalam arti luas.

Salah satu industri kecil menengah yang cukup berkembang di Kabupaten Semarang adalah industri kerajinan eceng gondok. Kerajinan eceng gondok merupakan kerajinan tangan dengan bahan dasar eceng gondok yang sudah dikeringkan dan diolah sedemikian rupa. Eceng gondok (Eichornia crassipes) memiliki kecepatan berkembang biak vegetatif yang sangat tinggi, salah satu danau atau waduk yang banyak tumbuh eceng gondok adalah obyek wisata Rawapening di Kabupaten Semarang. Satu batang eceng gondok dalam waktu 52 hari mampu menghasilkan tanaman baru seluas $1 \mathrm{~m} 2$ (Indriayu, 2015:51). Sampai dengan tahun 2015 persentase covering eceng gondok di perairan Danau Rawapening adalah 70\% atau seluas 1869 Ha dari luas total $2670 \mathrm{Ha}$.

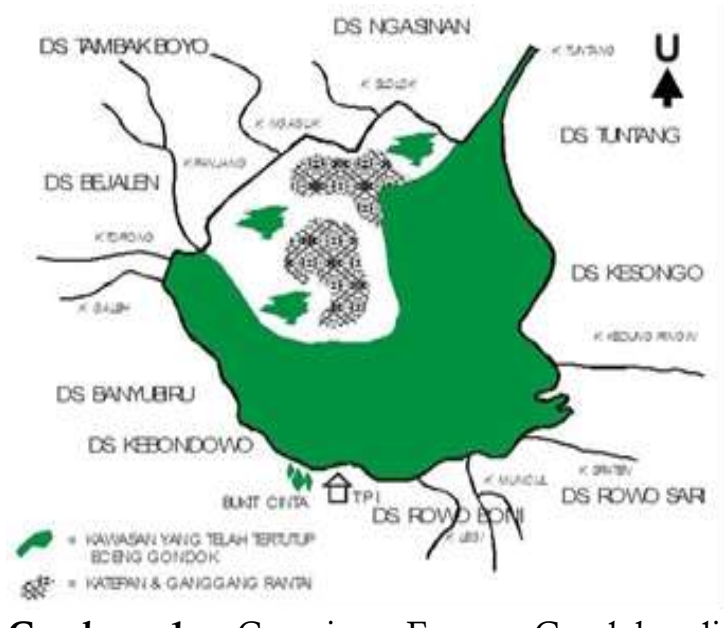

Gambar 1. Covering Eceng Gondok di Rawapening Kab. Semarang Tahun 2015 Sumber : Badan Lingkungan Hidup Kabupaten Semarang 
Apabila tanaman eceng gondok tersebut tidak dikendalikan populasinya, maka hampir seluruh permukaan waduk atau danau akan tertutup tanaman eceng gondok. Tertutupnya permukaan perairan menyebabkan berkurangnya jenis binatang air dan pendapatan petani di sekitarnya. Meskipun terdapat sisi negatif dari tanaman eceng gondok, tetapi banyak manfaat yang bisa diperoleh dari tanaman eceng gondok. Salah satunya dengan membuatnya menjadi berbagai macam kerajinan dengan menggunakan eceng gondok sebagai bahan dasarnya.

Tujuan industri adalah menghasilkan dan meningkatkan nilai guna suatu barang atau jasa, meningkatkan keuntungan, dan memperluas lapangan pekerjaan. Di era globalisasi saat ini mengakibatkan seluruh industri daerah berhadapan secara langsung, baik di pasar domestik maupun internasional dengan persaingan yang semakin tajam. Maka sangatlah penting bagi suatu industri untuk mengembangkan industrinya agar tidak kalah bersaing dan mampu bertahan melangsungkan usahanya. Industri kerajinan eceng gondok merupakan salah satu industri kecil yang mempunyai potensi baik dan tahan krisis, tetapi tidak berarti industri kecil tersebut tidak mengalami hambatan dan tantangan. Kemungkinan terjadinya suatu permasalahan dalam industri kecil terjadi pada industri kecil kerajinan eceng gondok di Kabupaten Semarang. Untuk lebih jelasnya lihat pada Gambar 2.

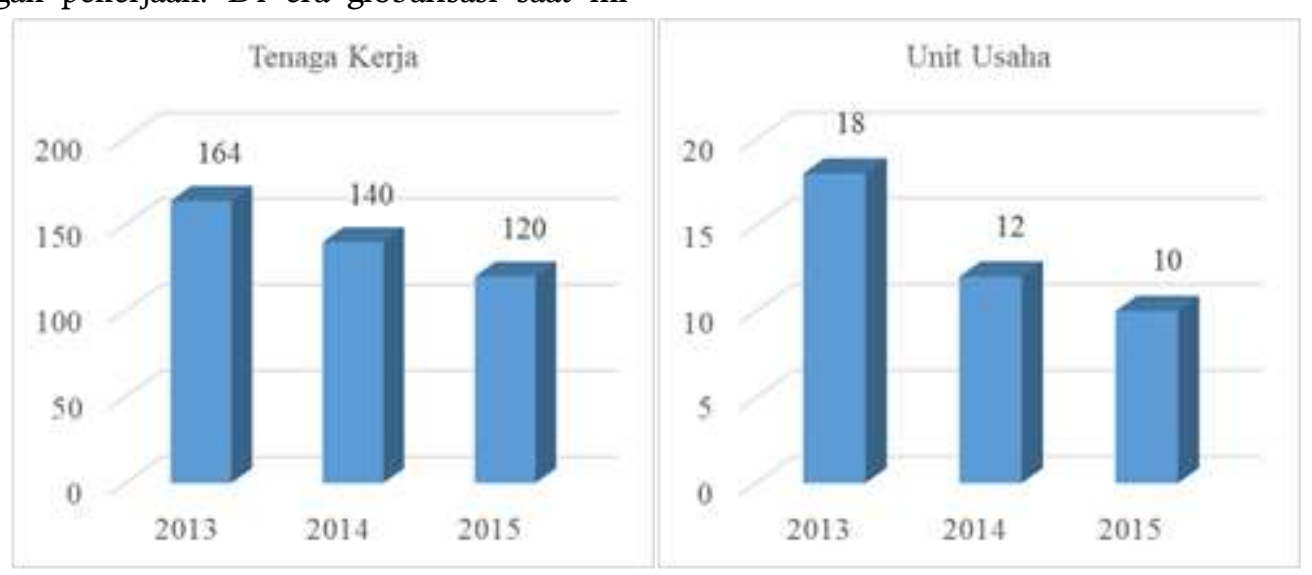

Gambar 2. Penurunan Jumlah Unit Usaha dan Tenaga Kerja Industri Kerajinan Eceng Gondok di Kabupaten Semarang Tahun 2013-2015

Sumber: Dinkop, UMKM, dan Perindag Kabupaten Semarang diolah, 2016

Berdasarkan Gambar 2. dapat dilihat bahwa terjadi penurunan jumlah unit usaha dan tenaga kerja pada industri kerajinan eceng gondok di Kabupaten Semarang. Pada tahun 2013 terdapat 18 unit usaha kerajinan eceng gondok dengan 164 tenaga kerja. Namun di tahun 2015 mengalami penurunan lagi menjadi hanya 10 unit usaha dengan jumlah tenaga kerja sebanyak 120 orang.

Sampai dengan tahun 2015 industri kerajinan eceng gondok yang masih bertahan adalah: Aryani Art, Koen Gallery, Aliya, Renita, Syarina Production, Abi Citra Kusuma, Sekar
Melati, Arema, I Boni, dan Production.Melihat prospek yang ada pada indutri kerajinan eceng gondok yang dapat menyerap banyak tenaga kerja, meningkatkan kesejahteraan pengusaha dan masyarakat sekitar serta memberikan kontribusi terhadap PDRB Kabupaten Semarang dan melihat permasalahan yang ada pada industri kecil kerajinan eceng gondok di atas, maka diperlukan upaya secara bersama-sama melalui kerjasama berbagai pihak seperti pemerintah, perguruan tinggi, swasta dan pelaku industri kerajinan eceng gondok agar turut andil dalam upaya pengembangan industri kerajinan eceng gondok di Kabupaten Semarang. 
Tujuan dari penelitian ini adalah untuk menganalisis masalah-masalah yang dihadapi industri kerajinan eceng gondok di Kabupaten Semarang dan strategi yang dapat dilakukan untuk mengembangkan industri kerajinan eceng gondook di Kabupaten Semarang.

\section{METODE PENELITIAN}

Jenis penelitian yang digunakan dalam penelitian ini adalah jenis penelitian kualitatif dengan menggunakan metode analisis deskriptif dan Analisis Hirarki Proses (AHP). Metode analisis analisis deskriptif digunakan untuk mengetahui permasalahan pada industri kerajinan eceng gondok Kabupaten Semarang. Sedangkan Analisis Hierarki Proses (AHP) untuk mengetahui strategi pengembangan industri kerajinan eceng gondok di Kabupaten Semarang.

Sumber data yang digunakan dalam penelitian ini berasal dari: (1) Data primer diperoleh dari hasil wawancara dan kuesioner AHP; (2) Data Sekunder, diperoleh dari dokumen publikasi/laporan penelitian dari dinas/instansi maupun sumber data lainnya yang menunjang.

Data primer diperoleh dari narasumber yang merupakan pemilik industri kerajinan eceng gondok di Kabupaten Semarang berjumlah 10 orang dengan melakukan wawancara. Selain itu data primer juga diperoleh dari keyperson untuk perumusan kebijakan dalam Analisis Hirarki Proses (AHP) yang diperoleh dari unsur pemerintah (DKUPP Kab. Semarang, Dinperindang Prov. Jawa Tengah, Dinkop UMKM Prov. Jawa Tengah, Bakorluh Prov. Jawa Tengah, Balitbang Prov. Jawa Tengah), akademisi/peneliti (Dosen FE Unnes), Klaster Klinting Kerajinan Eceng Gondok Kabupaten Semarang (Ketua Klaster), dan pemilik industri kerajinan eceng gondok di Kabupaten Semarang menggunakan angket/kuesioner AHP. Keyperson tersebut ditentukan berdasarkan kriteria kepakaran dan keterlibatannya di dalam kegiatan pengembangan industri kerajinan eceng gondok.

\section{HASIL DAN PEMB AHASAN}

Permasalahan pada industri kerajinan eceng gondok di Kabupaten Semarang dapat dikelompokkan menjadi empat aspek, yaitu aspek Sumber Daya Manusia (SDM), aspek pemasaran, aspek manajemen produksi, dan aspek teknologi.

Pada aspek SDM, permasalahan yang dihadapi adalah terkait pengetahun SDM tentang kewirausahaan, keterampilan teknis pada SDM, serta peranan tenaga penyuluh dan konsultasi usaha kecil. Keterampilan teknis pada SDM masih relatif rendah karena sebagian besar tenaga kerja yang ada hanya bisa membantu pekerjaan kasar dan hanya sebagian kecil saja yang bisa membuat kerajinan dengan baik. Peranan tenaga penyuluh dan konsultasi usaha kecil sudah cukup aktif, namun belum semua pemilik industri kerajinan eceng gondok di Kabupaten Semarang merasakan peranan tenaga penyuluh dan konsultasi usaha kecil tersebut.

Pada aspek pemasaran, permasalahan yang dihadapi industri kerajinan eceng gondok adalah terkait sarana dan prasarana pemasaran (rumah dagang/workshop), kemitraan usaha dengan perusahan/ pedagang besar, dan fasilitas kegiatan pameran. Pada umumnya pemilik industri belum memiliki tempat untuk memasarkan dan mempromosikan produknya, sebagian besar pemilik industri hanya memasarkan produk di rumahnya masingmasing. Jalinan kemitraan yang terbentuk antara industri kerajinan eceng gondok dengan perusahaan/pedagang besar juga mulai terhenti, salah satu penyebabnya adalah pihak industri kerajinan eceng gondok tidak mampu memenuhi tuntutan kuota produk setiap bulannya. Selanjutnya minat perajin untuk mengikuti kegiatan pameran juga masih relatif rendah, salah satu penyebabnya adalah fasilitas kegiatan pameran yang kurang memadai dan sempitnya stand yang disediakan.

Jika dilihat dari aspek manajemen produksi, permasalahan yang masih dihadapi industri kerajinan eceng gondok adalah terkait kemampuan manajemen dan teknis produksi pengolahan, desain dan inovasi produk, serta 
penerapan standarisasi produk. Produktivitas industri masih relatif rendah karena masih kurangnya kemampuan manajemen dan teknis produksi pengolahan. Hanya sebagian kecil industri yang melakukan pembagian kerja pada proses produksi usahanya. Desain produk dan inovasi produk juga masih sangat sederhana, selain dikarenakan terbatasnya pengetahuan tentang produk yang diminati oleh pasar, terbatasnya desain produk juga disebabkan oleh produksi yang hanya dilakukan ketika ada pesanan saja. Standarisasi produk juga belum diterapkan oleh industri kerajinan eceng gondok di Kabupaten Semarang.

Selanjutnya permasalahan yang dihadapi pada aspek teknologi adalah terkait kemampuan bidang penelitian untuk pengembangan teknologi (mesin/peralatan) baru, pengadaan teknologi (mesin/peralatan), dan penerapan dan pengembangan teknologi baru oleh pengusaha kecil. Pengembangan teknologi baru memang sudah mulai dikembangkan, hanya saja belum sesuai dengan kebutuhan dan kemampuan yang dimiliki industri kecil. Misalnya saja seperti mesin pengering eceng gondok, memang cukup membantu proses pengeringan, hanya saja daya yang dibutuhkan terlalu tinggi dan biaya pengadaannya juga cukup tinggi. Sebagian besar industri juga masih enggan menerapkan teknologi baru, mereka lebih menyukai teknologi sederhana yang lebih mudah pengoperasian dan perawatannya.

\section{Strategi Pengembangan Industri Kerajinan Eceng Gondok Melalui AHP}

Program pengembangan industri kerajinan eceng gondok terkait dengan beberapa aspek utama antara lain: aspek SDM, aspek pemasaran, aspek manajemen produksi dan aspek teknologi. Berdasarkan pendapat gabungan para keyperson menunjukkan bahwa aspek SDM (nilai bobot 0,463) merupakan kriteria paling penting yang perlu diperhatikan dalam strategi pengembangan industri kerajinan eceng gondok. Aspek berikutnya yang perlu diperhatikan adalah aspek pemasaran (nilai bobot 0,347 ); aspek manajemen produksi (nilai bobot 0,119); dan aspek teknologi (nilai bobot 0,071). Nilai inconsistency ratio $0,08<0,1$ (batas maksimum) yang berarti hasil analisis tersebut dapat diterima.

Tabel 1. Kriteria Pengembangan Industri Kerajinan Eceng Gondok

\begin{tabular}{lcc}
\hline \multicolumn{1}{c}{ Program } & Nilai Bobot & Keterangan \\
\hline $\begin{array}{l}\text { Berbasis Sumber Daya } \\
\text { Manusia }\end{array}$ & 0,463 & $\begin{array}{l}\text { Inconsistency } \\
\text { Ratio }=0,08\end{array}$ \\
Berbasis Pemasaran & 0,347 & \\
Berbasis Manajemen & 0,119 & \\
Produksi & & \\
Berbasis Teknologi & 0,071 & \\
\hline
\end{tabular}

Sumber : Hasil Pengolahan Data Penelitian (2016)

Terpilihnya aspek SDM sebagai prioritas utama yang harus diperhatikan dalam pengembangan industri kerajinan eceng gondok mencerminkan bahwa tingkat tingkat kemampuan dan keterampilan SDM pada industri kerajinan eceng gondok sangat erat kaitannya dengan program pengembangan industri kerajinan eceng gondok di Kabupaten Semarang.

Aspek pertama yang menjadi prioritas dalam pengembangan industri kerajinan eceng gondok di Kabupaten Semarang adalah aspek Sumber Daya Manusia (SDM). 
Tabel 2. Kriteria Sumber Daya Manusia (SDM)

\begin{tabular}{lll}
\hline Kriteria Aspek SDM & Nilai Bobot & Keterangan \\
\hline $\begin{array}{l}\text { Pelatihan dalam upaya } \\
\text { membudayakan }\end{array}$ & 0,208 & $\begin{array}{l}\text { Inconsistency } \\
=0,01\end{array}$ \\
kewirausahaan \\
$\begin{array}{l}\text { Pendidikan dan pelatihan } \\
\text { dalam }\end{array}$ & & \\
meningkatkan keterampilan & & \\
teknis \\
$\begin{array}{l}\text { Tenaga penyuluh dan } \\
\text { konsultasi } \\
\text { usaha kecil }\end{array}$ \\
\hline Sumber : Hasil Pengolahan Data Penelitian (2016)
\end{tabular}

Berdasarkan Tabel 2. dapat diketahui pendidikan dan pelatihan dalam meningkatkan keterampilan teknis merupakan alternatif yang paling menjadi prioritas dalam pengembangan industri kerajinan eceng gondok dengan persentase prioritas $63,2 \%$. Selanjutnya yang menjadi prioritas kedua adalah pelatihan dalam upaya membudayakan kewirausahaan dengan persentase prioritas $20,8 \%$ disusul tenaga penyuluh dan konsultasi usaha kecil dengan persentase prioritas $16 \%$. Implikasi penting dari hal tersebut adalah perlu dilakukannya pendidikan dan pelatihan sumber daya manusia/tenaga kerja secara lebih serius untuk meningkatkan kualitas dan daya saing baik antar sesama perajin/pengusaha kerajinan eceng gondok maupun dapat bersaing dengan kualitas produk pesaing dari luar negeri. Jika peningkatan dalam kualitas sumber daya manusia sudah tercapai dan berkelanjutan, maka hal ini akan mendorong tercapainya pengembangan industri kerajinan eceng gondok. Aspek kedua dalam strategi pengembangan industri kerajinan eceng gondok adalah aspek pemasaran.

Tabel 3. Kriteria Pemasaran

\begin{tabular}{lll}
\hline Kriteria Aspek SDM & Nilai Bobot & Keterangan \\
\hline $\begin{array}{l}\text { Rumah dagang dan pemasaran } \\
\text { usaha (workshop) }\end{array}$ & 0,402 & $\begin{array}{l}\text { Inconsistency Ratio }= \\
0,01\end{array}$ \\
$\begin{array}{l}\text { Kemitraan usaha dengan usaha } \\
\text { Besar }\end{array}$ & 0,439 & \\
Fasilitas kegiatan pameran & 0,160 & \\
\hline
\end{tabular}

Sumber : Hasil Pengolahan Data Penelitian (2016)

Berdasarkan Tabel 3. dapat diketahui kemitraan usaha dengan usaha besar merupakan alternatif yang paling menjadi prioritas dalam pengembangan industri kerajinan eceng gondok dari aspek pemasaran dengan persentase prioritas $43,9 \%$, disusul rumah dagang dan pemasaran usaha (workshop) $40,2 \%$ dan fasilitas kegiatan pameran $16 \%$. Implikasi penting dari hal tersebut adalah perlu dilakukannya pembentukan kemitraan antara industri kerajinan eceng gondok dengan pengusaha atau pedagang besar yang dapat menjadi pasar yang pasti bagi pihak perajin. Kemitraan dalam hal ini adalah kerjasama yang tidak hanya menguntungkan usaha/pedagang besar saja melainkan juga menguntungkan perajin kecil. Aspek ketiga yang perlu dipertimbangkan dalam pengembangan industri kerajinan eceng gondok di Kabupaten Semarang adalah aspek manajemen produksi. 
Tabel 4. Kriteria Manajemen Produksi

\begin{tabular}{lrll}
\hline \multicolumn{2}{l}{ Kriteria Aspek SDM } & Nilai Bobot & Keterangan \\
\hline $\begin{array}{l}\text { Kemampuan manajemen } \\
\text { dan teknis }\end{array}$ produksi & & $\begin{array}{l}\text { Inconsistency Ratio } \\
=0,04\end{array}$ \\
pengolahan & & \\
Desain dan inovasi produk & 0,400 & \\
$\begin{array}{l}\text { Penerapan standarisasi } \\
\text { produk }\end{array}$ & 0,271 & \\
\hline Sumber : Hasil Pengolahan Data Penelitian (2016)
\end{tabular}

Berdasarkan Tabel 4. dapat diketahui bahwa urutan prioritas dalam pengembangan industri kerajinan eceng gondok dari aspek manajemen produksi adalah desain dan inovasi produk dengan persentase prioritas $40 \%$, kemampuan manajemen dan teknis produksi pengolahan $32,9 \%$, dan penerapan standarisasi produk $27,1 \%$.

Hal ini menunjukkan bahwa alternatif utama dalam pengembangan industri kerajinan eceng gondok di Kabupaten Semarang yang terkait dengan aspek manajemen produksi adalah desain dan inovasi produk. Hal ini berkaitan dengan selera pasar dan juga daya saing produk di pasaran. Sehingga implikasi penting dari hal ini adalah perlu dilakukannya perbaikan desain produk kerajinan dan juga melakukan inovasi pada produk kerajinan yang ada agar tetap dapat bersaing baik antar sesama perajin/pengusaha kerajinan eceng gondok maupun dengan pesaing dari luar negeri.

Aspek terakhir yang perlu dipertimbangkan dalam pengembangan industri kerajinan eceng gondok di Kabupaten Semarang adalah aspek teknologi.

Tabel 5. Kriteria Teknologi

\begin{tabular}{lrll}
\hline Kriteria Aspek SDM & & Nilai Bobot & Keterangan \\
\hline $\begin{array}{l}\text { Kemampuan bidang } \\
\text { untuk pengembangan } \\
\text { baru }\end{array}$ & $\begin{array}{r}\text { teknolitiani } \\
\text { Bantuan }\end{array}$ & 0,455 & $\begin{array}{l}\text { Inconsistency Ratio } \\
=0,04\end{array}$ \\
(mesin/peralatan) & teknologi & 0,369 & \\
$\begin{array}{l}\text { Insentif bagi usaha kecil yang } \\
\text { menerapkan dan mengembangkan }\end{array}$ & 0,176 & \\
teknologi baru & & \\
\hline
\end{tabular}

Sumber : Hasil Pengolahan Data Penelitian (2016)

Berdasarkan Tabel 5. dapat diketahui kemampuan bidang penelitian untuk pengembangan teknologi baru merupakan alternatif yang paling menjadi prioritas dalam pengembangan industri kerajinan eceng gondok dari aspek pemasaran dengan persentase prioritas sebesar $45,5 \%$. Prioritas selanjutnya adalah bantuan teknologi (mesin/peralatan)

sebesar 36,9\% dan insentif bagi usaha kecil yang menerapkan dan mengembangkan teknologi baru sebesar $17,6 \%$. Implikasi penting dari hal ini adalah perlu dilakukannya peningkatan kemampuan bidang penelitian untuk pengembangan teknologi sehingga dapat membantu para perajin dalam memproduksi kerajinan eceng gondok. Jika aspek teknologi sudah menjadi salah satu prioritas penting dan mendesak, maka hal ini akan menjamin tercapainya pengembangan industri kerajinan eceng gondok di Kabupaten Semarang. Hal yang tidak kalah penting adalah sosialisasi terkait keuntungan dan manfaat penggunaan teknologi baru, sehingga para perajin bersedia menerapkan 
teknologi (mesin/peralatan) yang lebih efektif dan efisien tersebut.

\section{SIMPULAN}

Permasalahan industri kerajinan eceng gondok di Kabupaten Semarang pada aspek sumber daya manusia (SDM) adalah berkaitan dengan pengetahuan SDM/tenaga kerja tentang kewirausahaan, keterampilan teknis SDM/tenaga kerja, dan peranan tenaga penyuluh dan konsultasi usaha kecil. Sedangkan pada aspek pemasaran adalah berkaitan dengan sarana dan prasarana pemasaran (rumah dagang/workshop), kemitraan usaha dengan perusahaan/pedagang besar, dan fasilitas kegiatan pameran. Selanjutnya pada aspek manajemen produksi adalah berkaitan dengan kemampuan manajemen dan teknis produksi dan pengolahan, desain dan inovasi produk, dan penerapan standarisasi produk. Kemudian pada aspek teknologi adalah berkaitan dengan kemampuan bidang penelitian untuk pengembangan teknologi (mesin/peralatan) baru, pengadaan teknologi (mesin/peralatan), dan penerapan dan pengembangan teknologi baru oleh pengusaha kecil.

Strategi pengembangan industri kerajinan eceng gondok melalui AHP yang dilakukan terhadap 16 keyperson yang terdiri dari unsur pemerintah, akademisi/peneliti dan pelaku industri menunjukkan bahwa aspek sumber daya manusia $(0,463)$ merupakan aspek yang paling penting yang perlu diperhatikan dalam strategi pengembangan industri kerajinan eceng gondok di Kabupaten Semarang. Aspek berikutnya adalah aspek pemasaran (0,347), aspek manajemen produksi $(0,119)$, dan aspek teknologi $(0,071)$.

Pemerintah Daerah Kabupaten Semarang disarankan untuk lebih memfokuskan pengembangan industri kerajinan eceng gondok melalui peningkatan pengetahuan dan keterampilan teknis untuk para perajin melalui pendidikan dan pelatihan. Pendidikan dan pelatihan dapat dikembangkan bersamaan dengan penguatan fungsi klaster, sehingga antar perajin dapat bertukar informasi dan pengetahuan, peran penyuluh dan konsultasi usaha kecil harus lebih dari sekedar penyuluh namun juga harus sebagai pendamping usaha kecil. Hal ini penting mengingat pengusaha kecil/perajin kecil memerlukan sosok pendamping dalam menjalankan kegiatan usahanya.

\section{DAFTAR PUSTAKA}

.BPS. 2015. Kabupaten Semarang Dalam Angka. Badan Pusat Statistik. BPS Kabupaten Semarang.

. 2016. Jawa Tengah Dalam Angka. Badan Pusat Statistik. BPS Jawa Tengah.

Indriayu, Mintasih dan Dewi Kusuma Wardani. 2015. "Pengembangan Inovasi Produk dan Pengadministrasian Keuangan pada UKM Kerajinan Eceng Gondok di Desa Lopait". Prosiding Seminar Nasional 4th UNS SME's Summit \& Awards 2015. Hal. 50-57.

Kuncoro, Mudrajad. 2007. Ekonomika Industri Indonesia. Yogyakarta: Andi Offset.

Prasetyo, P. Eko. 2010. Ekonomi Industri. Yogyakarta: Beta Offset.

Papilo, Petir. 2014. "Strategi Pemberdayaan Masyarakat Pengrajin Rotan di Kota Pekanbaru". Jurnal Kewirausahaan. Vol. 13, No. 1, Januari-Juni 2014, Hal. 1-20.

Puspitasari, Nia Budi, dkk. 2012. "Strategi Pengembangan Usaha Kerajinan Eceng Gondok Sebagai Produk Unggulan Kabupaten Semarang Menggunakan Analisis Rantai Nilai". Jurnal Teknik Industri Undip. Vol. VII, No. 2, Mei 2012, Hal. 113-122.

Rusdarti. 2010. "Potensi Ekonomi Daerah dalam Pengembangan UKM Unggulan di Kabupaten Semarang". Jurnal Ekonomi dan Kebijakan. Volume 3 No. 2 Hal. 143-155. Semarang: Universitas Negeri Semarang.

Suci, Rahayu Puji dan Priyono. 2013. "Analysis Of Small Industries Development Strategy Craft Cindogo". Developing Country Studies. Vol. 3, No. 11, 2013, Hal. 19-29.

Sudantoko, Djoko. 2010. "Pengembangan Industri Batik Skala Kecil di Kabupaten dan Kota Pekalongan dengan Pendekatan Analysis Hierarchy Process (AHP)". P3M STIE Bank BPD Jateng. Vol. 6, No. 1, Juni 2010.

Sugiyono. 2014. Memahami Penelitian Kualitatif. Bandung: Alfabeta.

Sutanto, Himawan Arif, Djoko Sudantoko dan Slamet Maktub. 2011. "Strategi Peningkatan 
Fatmawati \& Deky Aji Suseno/ Economics Development Analysis Journal 7 (3) (2018)

Keberdayaan Industri Kecil Konveksi dengan Analysis Hierarchy Process". Jurnal Ekonomi dan Kebijakan. Vol. 5, No. 1, Maret 2012, Hal. $15-25$.

Taheri, Abbas Mohammad dan Keyvan Loloie. 2015. Strategic Planning of Production and Sale of Handicrafts in Iran Using AHP Method". Academic Journal of Research in Business and Accounting. Vol. 3, No. 3, June, 2015, Hal. 5261. 